Original Article (short paper)

\title{
Effects of different frequencies of physical training on electron transport chain and oxidative damage in healthy mice
}

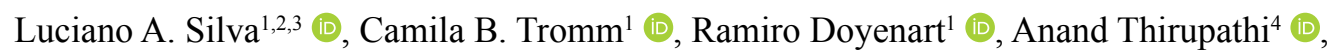 \\ Paulo Cesar Loock Silveira ${ }^{1}$ (D), Ricardo Aurinho Pinho ${ }^{4}$ (1)
}

\begin{abstract}
${ }^{1}$ Universidade do Extremo Sul Catarinense, UNESC, Laboratory of Exercise Psychophysiology, Advanced Aquatic Exercise Research Group, Criciúma, SC, Brazil; ${ }^{2}$ Faculdades Esucri, Escola superiror de Criciúma, ESUCRI; ${ }^{3}$ Centro Universitario Barriga Verde, UNIBAVE; ${ }^{4}$ Pontifícia Universidade Católica do Paraná, PUCPR, Laboratory of Exercise Biochemistry and Physiology, School of Medicine, Graduate Program in Health Science Head, Curitiba, PR, Brazil
\end{abstract}

\begin{abstract}
Aims: The present study investigated the effect of different frequencies (three and five times a week) on electron transport chain and oxidative stress after 8 weeks of run training. Methods: Eighteen male mice (CF1, $30-35 \mathrm{~g})$ were distributed into the following groups $(\mathrm{n}=6)$ : untrained (UT); trained three-time per week (T3) and trained five- time per week (T5). All training sessions were at the same intensity and duration (45min/day) in a treadmill for small animals. Forty-eight hours after the last training session, the animals were killed by decapitation and quadriceps (red portion) was removed and stored at $-70^{\circ} \mathrm{C}$. Succinate dehydrogenase (SDH), complexes I, II, II-III, IV and hydroperoxides were measured. Results: Training sessions for five times per week were more effective in increasing the mitochondrial respiratory chain enzyme activities (SDH, complexes I, II, II-III, IV) as well as in decreasing the formation hydroperoxides than sessions performed for three times training per week $(p<0.05)$. Conclusion: Our findings clearly showed that a higher the frequency of training session promotes a greater activity of the electron transport chain and consequently reduces the oxidative stress in healthy animals.
\end{abstract}

Keywords: frequency of exercise; training; respiratory chain; oxidative damage; adaptation.

\section{Introduction}

Mitochondrial oxygen flux enhances the ATP production in the skeletal muscle during physical exercise. ${ }^{1,2,3}$ It is well known that muscle adaptation to regular exercise involves mitochondrial biogenesis and regulate respiratory chain activities to compensate for energy demands. ${ }^{4}$

The beneficial effects of regular moderate exercise have been consistently reported in human and animal studies. Several studies have been carried out in the skeletal muscles of rats to determine the influence of exercise on the mitochondrial enzyme adaptation. ${ }^{2,3,5,6}$

In addition, contradictory concepts exist about the rate of electron transfer in the mitochondrial complexes (I, II, III, and IV) during muscle adaptations induced by exercise. Regular moderate exercise exhibited a beneficial effect in preventing the age-associated decline by a maintenance of the activities of mitochondrial complexes IV and I. ${ }^{7}$ Exhaustive exercise decreases mitochondrial respiratory control, causing an increase in free radicals. ${ }^{8}$ Venditti and colleagues ${ }^{9}$ were the first group to report that chronic endurance training of Wistar rats could reduce mitochondrial reactive oxygen species (ROS) production.

Numerous observational studies and well-designed exercise protocol intervene the outcome of clinical relevance particularly, different frequency of exercise is required to produce more benefit, which means identifying a new target in each individual in clinical practice must be prescribed by the different exercise frequencies. ${ }^{6,7,89}$ Also, determination of electron transport chain complexes activity and oxidative damages has a good clinical relevance. Different oxidative damages due to disturbances in the electron transport chain complexes lead a number of pathological conditions. Hence, it is important to develop a research to detecting if a different frequency of exercise sessions would reduce the oxidative damages due to electron transport chain. Also, the outcome of this aspect can help to understand the clinical importance of exercise frequency in relation to oxidative stress and its possible deleterious effects. Indeed, previous studies have shown that treadmill exercise modulates the oxidative stress parameters at a different frequency (five or seven times a week) ${ }^{2,3,5}$. However, no studies examined the effects of different frequencies (threeor five- time a week) on electron transport chain and oxidative stress. Thus, the present study investigated the effect of different frequencies of run training (three or five times a week) on electron transport chain activity and oxidative damages in healthy mice.

We hypothesized that physical training induces changes in muscle oxidative metabolism in a frequency-dependent manner in rats.

\section{Materials and Methods}

\section{Animal preparation}

The study protocol was reviewed and approved (protocol number 249/2013) by the Ethics Committee of the Universidade 
do Extremo Sul Catarinense, Criciúma, SC, Brazil, according to the Guidelines for Animal Care and Experimentation (Olert et al. 1993). A total of 18 male mice (CF1), a mean age of 3 months, weighing 30 to $35 \mathrm{~g}$, were housed in cages with a maximum of six animals per cage and with water and food ad libitum. The animals were kept on a 12-h light and 12-h dark cycle and were maintained at $23^{\circ} \mathrm{C}$.

\section{Training protocol}

The animals were divided into the following groups $(n=6)$ : untrained (UT); trained three times per week (T3) and trained five times per week (T5). All animals were accustomed to treadmill running for one week $(0.6 \mathrm{Km} / \mathrm{h}$ without inclination for $10 \mathrm{~min})$. After the adaptation period, the trained groups were submitted to running training for 8 weeks. All training sessions were the same intensity and duration (approximately $75 \%$ and $81 \%$ VO2max - 45min/day of running continuously). ${ }^{10}$

\section{Sacrifice protocol}

Forty-eight hours after the last training session, the animals were killed by decapitation. The quadriceps (red portion) was surgically removed and immediately stored at $-70^{\circ} \mathrm{C}$ for later analysis.

\section{Biochemical Analyses}

\section{Homogenate preparation}

The quadriceps muscle was homogenized $(1: 10, \mathrm{w} / \mathrm{v})$ in SETH buffer (250 mM sucrose, $2 \mathrm{mM}$ EDTA, $10 \mathrm{mM}$ Trizma base, 50 $\mathrm{IU} / \mathrm{mL}$ heparin, $\mathrm{pH}$ 7.4). The homogenates were centrifuged at $800 \mathrm{~g}$ for $10 \mathrm{~min}$ and the supernatants were kept at $-70^{\circ} \mathrm{C}$ until use for determination of succinate dehydrogenase (SDH) and mitochondrial respiratory chain enzyme activities (complexes I, II, II-III and IV). The maximal period between homogenate preparation and enzyme analysis was always less than 5 days.

\section{Succinate Dehydrogenase (SDH)}

Phenazine oxireductase (soluble succinate dehydrogenase - SDH) was measured by the decrease in absorbance due to the reduction of 2, 6-dichloroindophenol (DCIP) at $600 \mathrm{~nm}$ with 700 $\mathrm{nm}$ as the reference wavelength in the presence of phenazine methasulphate. ${ }^{11}$

\section{Mitochondrial respiratory chain enzyme activities}

Mitochondrial respiratory chain enzyme activities: On the day of the assays, the samples were frozen and defrosted
(1:20) in SETH buffer (0.32 M sucrose, $1 \mathrm{mM}$ EDTA, $10 \mathrm{mM}$ Tris-HCL, pH 7.4) three times to fully expose the enzymes to substrates and achieve maximal activities. NADH dehydrogenase (complex I) was evaluated, according to the method described by Cassina \& Radi $^{12}$, by measuring the rate of NADH-dependent ferricyanide reduction at $420 \mathrm{~nm}$. The activities of succinate: DCIP oxidoreductase (complex II) and succinate: cytochrome c oxidoreductase (complex II-III) were determined according to the method of Fischer et al. ${ }^{11}$ Complex II activity was measured by following the decrease in absorbance, due to the reduction in 2,6-DCIP at $600 \mathrm{~nm}$. Complex II-III activity was measured by cytochrome c reduction from succinate. The activity of cytochrome c oxidase (complex IV) was assayed, according to the method described by Rustin et al. ${ }^{13}$, and measured by following the decrease in absorbance due to the oxidation of previously reduced cytochrome c at $550 \mathrm{~nm}$. The activities of the mitochondrial respiratory chain complexes were expressed as $\mathrm{nmol} / \mathrm{min} \mathrm{mg}$ protein.

\section{Oxidative damage}

The development of TBARS during the acid-heating reaction was used as an index of lipid peroxidation ${ }^{14}$ BrieXy, the samples

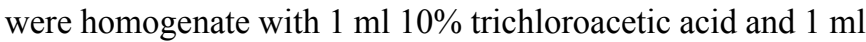
$0.67 \%$ thiobarbituric acid and then heated in a boiling water for 30 minutes. TBARS were determined by the absorbance at 535 nm using 1,1,3,3-tetramethoxypropane (Sigma Chemical) as an external standard. Results were expressed as malondialdehyde (MDA) equivalents per $\mathrm{mg}$ of protein.

\section{Protein Determination}

The amounts of proteins in the samples tested for respiratory chain enzymes activities and oxidative damage markers were determined using the Lowry method. ${ }^{15}$

\section{Statistical Analysis}

The data were expressed as means and standard errors of a mean (mean \pm SEM), and analyzed statistically by twoway analysis of variance (ANOVA), followed by the Tukey's HSD post-hoc test. The level of significance was set at $95 \%$ $(p<0.05)$. The software used for analysis of the data was the Statistical Package for the Social Sciences (SPSS), version 17.0 for Windows.

\section{Results}

Succinate Dehydrogenase (SDH): Figure 1 shows a significant increase in SDH in both trained groups (T3: $69.6 \pm 6$ and T5: $116.4 \pm 16 \mathrm{nmol} / \mathrm{min} / \mathrm{mg}$ protein) when compared with UT group $(27.3 \pm 4.6 \mathrm{nmol} / \mathrm{min} / \mathrm{mg}$ protein $)$ that was dependent of the training frequency. $(\mathrm{p}<0.05)$ 
Mitochondrial respiratory chain enzyme activities: Regarding Complex I, our findings show an increase in the NADH dehydrogenase activities in both trained groups (T3: $255 \pm 19$ and T5: $444 \pm 55 \mathrm{nmol} / \mathrm{min} / \mathrm{mg}$ protein) when compared with UT group (104 $\pm 19 \mathrm{nmol} / \mathrm{min} / \mathrm{mg}$ protein). In a similar manner, increased activity in the complex II was found (T3: $87 \pm 3$ and T5: $159 \pm 35 \mathrm{nmol} / \mathrm{min} / \mathrm{mg}$ protein) when compared with UT group $(34 \pm 4 \mathrm{nmol} / \mathrm{min} / \mathrm{mg}$ protein). The oxidoreductase cytochrome c (Complex III) activity was also increased in both trained groups (T3: $54 \pm 2$ and T5: $154 \pm 15 \mathrm{nmol} / \mathrm{min} / \mathrm{mg}$ protein) when

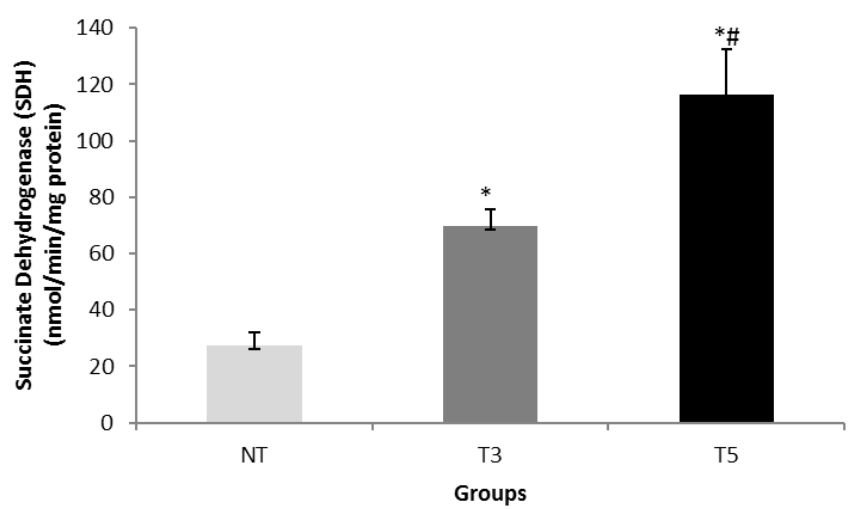

Figure 1 : Succinate Dehydrogenase (SDH) levels measure in the quadríceps in healthy mice trained in a treadmill for three-time (T3) or five-time (T5) per week.

The values are presented as Means $\pm \mathrm{SEM}$ and the results expressed in $\mathrm{nmol} / \mathrm{min}$ mg protein. $(*)$ Significant difference in relation to the UT, T5* and T3 $\mathrm{p}<0.05$. compared with UT group $(21 \pm 1.8 \mathrm{nmol} / \mathrm{min} / \mathrm{mg}$ protein $)$. The cytochrome c oxidase activity (complex IV) was also augmented in T3 and T5 groups, $421 \pm 66$ and $1455 \pm 110 \mathrm{nmol} / \mathrm{min} / \mathrm{mg}$ protein, respectively) when compared with UT group (159 \pm $110 \mathrm{nmol} / \mathrm{min} / \mathrm{mg}$ protein). Data are summarized in Table 1.

Oxidative damage: Both training programs, T3 and T5 promoted a decrease in the TBARS levels, $0.07 \pm 0.016$ and $0.02 \pm 0.013 \mathrm{nmol} / \mathrm{mg}$ protein, respectively) when compared with NT group $(0.14 \pm 0.008 \mathrm{nmol} / \mathrm{mg}$ protein) that was dependent of the training frequency. Figure 2 illustrates the data.

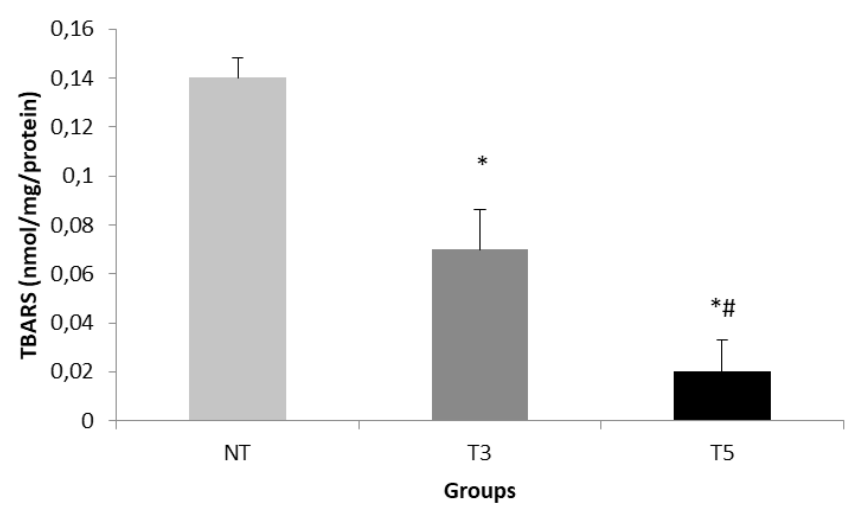

Figure 2: TBARS measurement in the quadriceps muscle from healthy mice trained in a treadmill for three-time (T3) or five-time (T5) per week

The values are presented as Means $\pm \mathrm{SEM}$ and the results expressed in $\mathrm{nmol} / \mathrm{min}$ $\mathrm{mg}$ protein. Significant difference in relation to the UT, and $\left(\mathrm{T} 5^{\sharp}\right) \mathrm{T} 3 \mathrm{p}<0.05$.

Table 1: Mitochondrial respiratory chain enzyme activities in the quadriceps muscle from healthy mice trained in a treadmill for three-time (T3) or five-time (T5) per week.

\begin{tabular}{lccc}
\hline & NT & T3 & T5 \\
\hline Complex I (nmol/min/mg protein) & $104 \pm 19$ & $255 \pm 19^{*}$ & $444 \pm 55^{* \#}$ \\
Complex II (nmol/min/mg protein) & $34 \pm 4$ & $87 \pm 3^{*}$ & $159 \pm 35^{* \#}$ \\
Complex III (nmol/min/mg protein) & $21 \pm 1.8$ & $54 \pm 2^{*}$ & $154 \pm 15^{* \#}$ \\
Complex IV (nmol/min/mg protein) & $159 \pm 110$ & $421 \pm 66^{*}$ & $1455 \pm 110^{* \#}$ \\
\hline
\end{tabular}

The values are presented as Means \pm SEM and the results expressed in $\mathrm{nmol} / \mathrm{min} \mathrm{mg}$ protein. Significant difference in relation to the UT, and $\left(\mathrm{T} 5^{\#}\right) \mathrm{T} 3 \mathrm{p}<0.05$

\section{Discussion}

The findings of the present study demonstrate that; (1) Run training at a frequency of three- and five-time per week increases significantly the mitochondrial function and decreases the oxidative damage in healthy mice; (2) Run training at a frequency of five-time per week was more effective in increasing mitochondrial function as well as in reducing oxidative stress measured by TBARS than those performed for three-times per week.

Several studies have determined the influence of exercise training on mitochondrial enzyme adaptation in the skeletal muscle of rats..$^{3,16,17}$ Endurance training is known to induce several skeletal muscle adaptations such as glycolysis ${ }^{18}$, alterations in the Krebs cycle ${ }^{19}$, fatty acid $\beta$-oxidation ${ }^{20}$ and electron transport chain. ${ }^{3,21}$ The SDH activity is widely used as a metabolic marker for muscle oxidative capacity. ${ }^{22,23}$ Our data show that run exercising for five times per week promoted a greater increase in the SDH activity than exercising for three times a week. Indeed, previous studies observed increase in SDH activity after endurance training (3 times per week) ${ }^{24}$ and four times per week ${ }^{25}$. Confirming and extending thoses findings, our results show that weekly frequency interferes with the activity of SDH enzyme.

Previous studies in our laboratory have demonstrated that 8 weeks of running is necessary to achieve complete 
mitochondrial respiratory chain enzyme activities. ${ }^{6}$ We found that training frequency of five times per week increased the activity of enzymes of skeletal muscle from mice (Complex I, II,III,IV) as compared with three-time per week or at rest. In agreement, Boveris and Navarro ${ }^{26}$ demonstrated that 24 weeks of training increased the complex IV activity for $12-32 \%$ whereas Menshikova, Ritov, Toledo, Ferrell, Goodpaster, Kelley ${ }^{22}$ showed that increases in enzymatic activity of the ETC I and IV following a 16-week exercise training program. This increase in respiratory chain enzyme activities might be explained by mitochondrial biogenesis that occurs in response to the increased cellular ATP demand ${ }^{27}$ induced by physical exercise. Molecular cellular aspects such as PGC-1 $\alpha$ expression may be robustly induced by exercise training ${ }^{28}$ resulting in mitochondrial biogenesis with an increased oxidative phosphorylation capacity and a consequently greater capacity for endurance training. ${ }^{27}$

Several studies have shown that exercise training reduces the oxidative stress. ${ }^{3,5,6} \mathrm{We}$ observed that a higher training frequency reduced the oxidative stress biomarker. Likely, this can be due to an adaptation of the enzymatic antioxidant defense systems and the resistance of tissue to the oxidative damages induced by physical training ${ }^{2,3,6}$. Animals frequently exposed to exercise training have shown less oxidative damage..$^{30}$ Thus, run training at frequency of five times per week was more effective in reducing oxidative stress than three times. Previous studies from our laboratory have shown a reduction in lipid peroxidation after 8 weeks of aerobic exercise training (five times per week) in muscle ${ }^{6}$ and liver from mice. ${ }^{3}$ Regular exercise lead to an adaptation of a specific organs or tissues associated with decreased oxidative damage and improvements in aerobic metabolism. This is largely due to the upregulation of endogenous antioxidant enzymes such superoxide dismutase and glutathione peroxidase that are activated by training. ${ }^{30-33}$

In summary, our findings show that a higher frequency of run training is more effective in increasing the electron transport chain activity as well as in reducing the oxidative stress.

\section{References}

1. Boveris A, Chance B. The mitochondrial generation of hydrogen peroxide. General properties and effect of hyperbaric oxygen. J Biochem. 1973;134 (3): 707-716.

2. Pinho RA, Andrades ME, Oliveira MR, Pirola AC, Zago MS, Silveira PC, et al. Imbalance in SOD/CAT activities in rat skeletal muscles submitted to treadmill training exercise. Cell Biol Int. 2006;30(10):848-53.

3. Silva LA, Pinho CA, Rocha LG, Tuon T, Silveira PC, Pinho RA. Effect of different models of physical exercise on oxidative stress markers in mouse liver. Appl Physiol Nutr Metab. 2009;34(1): 60-5.

4. Kang C, O'Moore KM, Dickman R, Ji LL. Exercise activation of muscle peroxisome proliferator-activated receptor-gamma coactivator-1alpha signaling is redox sensitive. Free Radic Biol Med. 2009; 47(10):1394-400.

5. Aguiar AS, Tuon T, Pinhom CA., Silvam LA, Andreazzam AC, Kapczinskim F, et al. Intense exercise induces mitochondrial dysfunction in mice brain. Neurochem Res. 2008; 33(1):51- 58.
6. Silva LA, Pinho CA, Scarabelot KS, Fraga DB, Volpato AM, Boeck $\mathrm{CR}$, et al. b. Physical exercise increases mitochondrial function and reduces oxidative damage in skeletal muscle. Eur J Appl Physiol. 2009;105(6): 861-7.

7. Navarro A, Gomez C, López-Cepero JM, Boveri A Beneficial effects of moderate exercise on mice aging: survival, behavior, oxidative stress, and mitochondrial electron transfer. Am J Physiol Regul Integr Comp Physiol. 2004;286(3): 505-11.

8. Davies KJ, Quintanilha AT, Brooks GA, Packer L. Free radicals and tissue damage produced by exercise. Biochem. Biophys Res. Commun 1982;107(4): 1198-1205.

9. Venditti P, Masullo P, Di Meo S. Effect of training on $\mathrm{H} 2 \mathrm{O} 2$ release by mitochondria from rat skeletal muscle. Arch Biochem Biophys 1999;372(3): 315-320.

10. Fernando P, Bonen A, Hoffman-Goetz L. Predicting submaximal oxygen consumption during treadmill running in mice. Can $\mathrm{J}$ Physiol Pharmacol. 1993;71(10): 854-7

11. Fischer JC, Ruitenbeek W, Berden JA, Trijbels JM, Veerkamp JH, Stadhouders AM, et al. Differential investigation of the capacity of succinate oxidation in human skeletal muscle. Clin Chim Acta. 1985;153(1): 23-26.

12. Cassina A, Radi R. Differential inhibitory Aation of nitric oxide and peroxynitrite on mitochondrial electron transport. Arch Biochem Biophysics. 1996;328 (2):309-316.

13. Rustin P, Chretien D, Bourgeron T, Gerard B, Rotig A, Saudubray $\mathrm{JM}$, et al. Biochemical and molecular investigations in respiratory chain deficiencies. Clin Chim Acta. 1994;228(1): 35-51.

14. Draper HH, Hadley M (1990) Malondialdehyde determination as index of lipid peroxidation. Meth Enzymol 186:421-43.

15. Lowry OH, Rosebough NG, Farr AL, Randall RJ. Protein measurement with the folin phenol reagent. J Biol Chem. 1951;193(1): 265-275.

16. De Lisio M, Kaczor JJ, Phan N, Tarnopolsky MA, Boreham DR, Parise G. Exercise training enhances the skeletal muscle response to radiation-induced oxidative stress. Muscle Nerve. 2011;43(1): 58-64.

17. Strobel NA, Peake JM, Matsumoto A, Marsh SA, Coombes JS, Wadley GD. Antioxidant Supplementation Reduces Skeletal Muscle Mitochondrial Biogenesis. Med Sci Sports Exerc. 2011;43(6):1017-24

18. Vogt M, Puntschart A, Geiser J, Zuleger C, Billeter R, Hoppeler H. Molecular adaptations in human skeletal muscle to endurance training under simulated hypoxic conditions. J Appl Physiol. 2001; 91(1): 173-82.

19. Hoppeler H, Fluck M. Plasticity of skeletal muscle mitochondria: structure and function. Med Sci Sports Exerc. 2003;35(1): 95-104.

20. Jong-Yeon K, Hickner RC, Dohm GL, Houmard JA. Long- and medium-chain fatty acid oxidation is increased in exercise-trained human skeletal muscle. Metabolism 2002. 51(4):460-464.

21. Daussin FN, Zoll J, Ponsot E, Dufour SP, Doutreleau S, Lonsdorfer E, et al, Training at high exercise intensity promotes qualitative adaptations of mitochondrial function in human skeletal muscle. J Appl Physiol. 2008;104(5): 1436-41.

22. Menshikova EV, Ritov VB, Toledo FG, Ferrell RE, Goodpaster $\mathrm{BH}$, Kelley DE. Effects of weight loss and physical activity on skeletal muscle mitochondrial function in obesity. Am J Physiol Endocrinol Metab. 2005;288(4): 818-25. 
23. Davison GW, Morgan RM, Hiscock N, Garcia JM, Grace F, Boisseau $\mathrm{N}$ et al. Manipulation of systemic oxygen flux by acute exercise and normobaric hypoxia: implications for reactive oxygen species generation. Clin Sci. 2006;110(1):133-41

24. Chilibeck PD, Bell GJ, Socha T, Martin T. The effect of aerobic exercise training on the distribution of succinate dehydrogenase activity throughout muscle fibres. Can J Appl Physiol. 1998;23(1):74-86.

25. Morton JP, Croft L, Bartlett JD, Maclaren DP, Reilly T, Evans L, et al. Reduced carbohydrate availability does not modulate training-induced heat shock protein adaptations but does upregulate oxidative enzyme activity in human skeletal muscle. J Appl Physiol. 2009;106(5):1513-21.

26. Boveris A, Navarro A. Systemic and mitochondrial adaptive responses to moderate exercise in rodents.Free Radic Biol Med. 2008;44(2): 224-9.

27. Kang C, O’Moore KM, Dickman R, Ji LL. Exercise activation of muscle peroxisome proliferator-activated receptor-gamma coactivator-1alpha signaling is redox sensitive. Free Radic Biol Med. 2009;47(10):1394-400.

28. Baar K, Wende AR, Jones TE, Marison M, Nolte LA, Chen M, et al. Adaptations of skeletal muscle to exercise: rapid increase in the transcriptional coactivator PGC-1. FASEB J.2002;16(14):1879-86.

29. Jackson MJ. Free radicals generated by contracting muscle: by-products of metabolism or key regulators of muscle function? Free Radic Biol Med. 2008;15(2): 132-41.

30. Gomez-Cabrera MC, Domenech E, Viña J. Moderate exercise is an antioxidant: upregulation of antioxidant genes by training. Free Radic Biol Med. 2008;44(2): 126-31.
31. Halliwell B, Gutteridge J. Free Radicals in Biology and Medicine. Oxford University Press, Oxford UK. 2007

32. Hollander J, Fiebig R, Gore M, Ookawara T, Ohno H, Ji LL. Superoxide dismutase gene expression is activated by a single bout of exercise in rat skeletal muscle. Pflügers Archiv. Eur J Physiol. 2001;442(3): 426-34.

33. Ji LL, Gomez-Cabrera MC, Steinhafe LN, Vina J. Acute exercise activates nuclear factor (NF)-kappaB signaling pathway in rat skeletalmuscle. FASEB J. 2004;18(13): 1499-506.

\section{Corresponding author}

\section{Luciano A. Silva}

Universidade do Extremo Sul Catarinense, UNESC, Laboratory of Exercise Psychophysiology, Advanced Aquatic Exercise Research Group, Criciúma, SC, Brazil

Av. Universitária, 1105 Bairro Universitário - 88806-000 - Criciúma - SC/Brazil.

Email: luciano_acordi@yahoo.com.br

Manuscrip received on January 4, 2018

Manuscript accepted on September 8, 2018

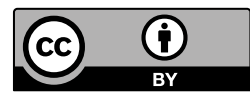

Motriz. The Journal of Physical Education. UNESP. Rio Claro, SP, Brazil - eISSN: 1980-6574 - under a license Creative Commons - Version 3.0 